\title{
Conflict of Laws on Occupational Accident Death Benefits: Presented with Actual Cases in Taiwan
}

\author{
By Chi-Hsin Wu, Ding-Hua Lin \& Yun Chen Yu \\ National Chung Cheng University
}

Abstract- When a worker dies due to an occupational accident, the labor insurance death benefit being applied for by his/her survivors subject to more conditions due to the revision of the Act. When the survivor does not meet the requirements, the labor insurance will not be paid. At this time, the survivor of the occupational accident worker shall instead turn to the employer for compensation to pay the labor insurance premium as the Bureau of Labor Insurance did not pay. The employer had to pay out of its pocket to compensate the survivor for the absurdity of the death compensation by the Labor Standards Act. A large company can take care of family members in terms of corporate responsibility or financial resources, if it is a small and medium-sized enterprise or even a microenterprise, it cannot pay this huge amount, and family members have to fight for compensation through litigation. However, it is not commonly known that the premiums of the labor accident insurance are not shared by the government or workers, and $100 \%$ of the total amount is paid by the employer.

Keywords: occupational accident; death benefit; conflict of laws.

GJHSS-H Classification: JEL Code: J28, J83

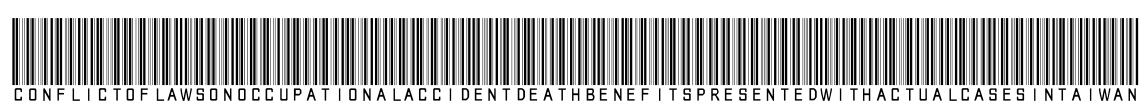

Strictly as per the compliance and regulations of:

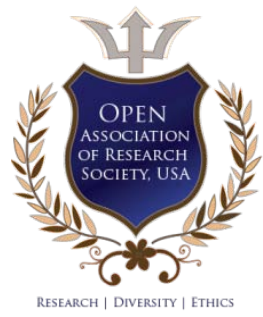

(c) 2021. Chi-Hsin Wu, Ding-Hua Lin \& Yun Chen Yu. This is a research/review paper, distributed under the terms of the Creative Commons Attribution-Noncommercial 3.0 Unported License http://creativecommons.org/licenses/by-nc/3.0/), permitting all noncommercial use, distribution, and reproduction in any medium, provided the original work is properly cited. 


\title{
Conflict of Laws on Occupational Accident Death Benefits: Presented with Actual Cases in Taiwan
}

\author{
Chi-Hsin $\mathrm{Wu}^{\alpha}$, Ding-Hua Lin ${ }^{\sigma} \&$ Yun Chen $\mathrm{Yu}{ }^{\rho}$
}

Abstract When a worker dies due to an occupational accident, the labor insurance death benefit being applied for by his/her survivors subject to more conditions due to the revision of the Act. When the survivor does not meet the requirements, the labor insurance will not be paid. At this time, the survivor of the occupational accident worker shall instead turn to the employer for compensation to pay the labor insurance premium as the Bureau of Labor Insurance did not pay. The employer had to pay out of its pocket to compensate the survivor for the absurdity of the death compensation by the Labor Standards Act. A large company can take care of family members in terms of corporate responsibility or financial resources, if it is a small and medium-sized enterprise or even a microenterprise, it cannot pay this huge amount, and family members have to fight for compensation through litigation. However, it is not commonly known that the premiums of the labor accident insurance are not shared by the government or workers, and $100 \%$ of the total amount is paid by the employer.

Article 59 of the Labor Standards Act adopts a nofault compensation system for occupational accident compensation. Regarding occupational accidents, most previous research focused on compensation, contractual agreements, and tort liability issues in the Labor Standards Act. There are few death benefits in labor insurance and compensation for occupational accident deaths in Subparagraph 4, Paragraph 1, Article 59 of the Labor Standards Act to discuss the interaction of the issues between the two. In the past, conflicts between the two were rare; however, with the declining birthrate, same-sex marriage, and the revised labor insurance system in 2009, they gradually emerged.

This research tries to find a reasonable way from the conflict between the death benefit of labor insurance coverage for occupational accident insurance and the death compensation of Subparagraph 4, Paragraph 1, Article 59 of the Labor Standards Act, as a balance between the labor and management when an occupational accident occurs. It can also avoid excessively aggravating the employer's responsibilities to protect both labor and enterprise development.

Keywords: occupational accident; death benefit; conflict of laws.

\section{INTRODUCTION}

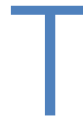
he International Labor Organization (ILO) has been vigorously promoting workplace safety programs since 2001. However, in recent years, there has

Author a: Department of Labor Relations, National Chung Cheng University, Taiwan. e-mail: osmond@mai12000.com.tw

Author $\sigma \rho$ : Department of Finance, National Changhua University of Education, Taiwan. been an average of 300,003,700 workplace accidents worldwide each year. Every day, about 6,300 workers are "injured and die at work." More than 2.3 million workers died at work each year ${ }^{1}$.

The labor force is the silent giant behind Taiwan's economic growth, and labor safety is the gear that maintains business operations. According to statistics from the Bureau of Labor Insurance, Taiwan has about 50,000 occupational accidents every year, causing workers to be injured, disabled, handicapped, and even die. Taking 2019 as an example (as shown in Table 1), the number of applications for occupational accidents is still as high as nearly 50,000 cases, among which 512 persons died due to occupational injuries or occupational diseases. ${ }^{2}$ For a total of 69 years from 1950 to 2019, the number of deaths due to occupational injuries alone was 59,346 persons, the average annual death toll is 860 persons, and labor insurance payments amounted to NT\$32,850,618,714 ${ }^{3}$. Every occupational accident is a story woven by laborers with their disabled bodies. The occupational accident statistics of the Bureau of Labor Insurance do not include the insurance of employed workers under agricultural insurance and fishery insurance. There is also an unwillingness to increase insurance due to card debts or accidents caused by employers with less than four uninsured persons and friends of occupational accident workers.

\footnotetext{
${ }^{1}$ Al-Tuwaijri, S., Fedotov, I., Feitshans, I., Gifford, M., \& Gold, D. XVIII World Congress on Safety and Health at Work.

${ }^{2}$ The website of the Bureau of Labor Insurance, https://events.bli.gov. $\mathrm{tw} / \mathrm{report} /$ reportY.aspx? $\mathrm{y}=108 \& \mathrm{f}=\mathrm{h} 350$, was last viewed on June 30, 2020.

${ }^{3}$ The website of the Bureau of Labor Insurance, https://www.bli.gov. tw/0021061.html, last viewed on June 30, 2020.
} 
Table 1: Number of occupational injuries and labor insurance payment amount in 2019

\begin{tabular}{|c|c|c|c|}
\hline Total & Injury and illness & Disability & Death \\
\hline \multicolumn{4}{|c|}{ Occupational injuries } \\
\hline 49326 persons & 46723 person & 2118 persons & 485 persons \\
\hline \multicolumn{4}{|c|}{ Occupational diseases } \\
\hline 744 persons & 542 persons & 175 persons & 27 persons \\
\hline
\end{tabular}

Data source: Bureau of Labor Insurance website,

https://events.bli.gov.tw/report/reportY.aspx?y=108\&f=h350.

Wang, Cheng, Wang, and Guo (2009) explained that the occupational accident compensation system in Taiwan is currently based on the occupational accidents in the Labor Insurance Act, with "negligence" and "social insurance" as the legislative principles; however, there is also the "no-fault" compensation liability imposed by the Labor Standards Act on employers, and the Civil Code and Occupational Safety and Health Act imposes "negligence" civil compensation and criminal liabilities on employers. Therefore, the overall design of the occupational accident compensation system and the related laws and regulations in Taiwan are very complicated. As a result, not only are payment calculation methods different, the applicability and mutual interaction between them are also quite complicated, which is ultimately detrimental to the protection of rights for workers or family members who have experienced occupational accidents. Therefore, Chen (2008) doubts whether occupational accident workers can receive compensation quickly. It may not protect the victims and their families according to the design and purpose of the occupational accident compensation system. The occupational accident insurance rates are currently divided into industryspecific accident rates and "on and off duty" accident rates, and they are adjusted every three years. For the insured units that employ more than a certain number of employees, the industry-specific accident rate mentioned in the preceding paragraph adopts the Merit Rate System, based on the ratio of the total amount of occupational accident insurance payments in the previous three years to the total amount of occupational accident insurance premiums payable, which is adjusted annually by the insurer under regulations. Another important law to protect workers from occupational accidents is the Act for Protecting Worker of Occupational Accidents, in the funding source, in addition to the budget that the central competent authority should prepare, the rest is collected from the occupational accident insurance of the labor insurance fund in a referral of the balance of expenditure, and an amount of more than $40 \%$ and less than $60 \%$ of the previous year's income and expenditure balance shall be allocated annually.

In 2018, the "Actuarial and Financial Valuation for Occupational Accident Insurance Rates of Labor
Insurance" was entrusted by the bureau of Labor Insurance, the Ministry of Labor, and it also mentioned that the current occupational accident insurance fund has a surplus of about NT\$20.8 billion (actuarial base date is December 31, 2017). Therefore, labor occupational accident insurance is not like the general accident insurance of labor insurance, which has bankruptcy concerns.

Not only that, for the death benefit of occupational accident compensation which is the frontline labor insurance, Article 65 of the Act stipulates that survivors' pension benefits and survivors' allowance shall be payable to the entitled survivors(s) according to the order prescribed below: 1. spouse, son and daughter; 2. father and mother; 3. grandfather and grandmother; 4. grandson and granddaughter; 5.brother(s) and sister(s). Survivors listed on the rear order as stipulated in the previous paragraph are not entitled to apply for survivor's pension benefits or survivor's allowance if survivors listed on the front still exist. Among them, the fourth-ranked grandchildren and fifth-ranked siblings must receive survivor's pension or survivor's allowance and shall also be eligible for support. This part is following Subparagraph 4, Paragraph 1, Article 59 of Labor Standards Act which provided that the order of receiving death compensation is the same, but the fourth-ranked grandchildren and fifth-ranked siblings in the order of receiving death compensation in Subparagraph 4, Paragraph 1, Article 59 of the Labor Standards Act are not as dependent on the labor insurance limits. (It is collated as Table 2). This situation has created the phenomenon that the employer does not pay the labor insurance, but the employer has to pay for occupational accident compensation. Moreover, after the implementation of the amendments in July 2008, for a labor insurance insured person who has been insured for the first time, in the event of occupational injury resulting in death, by Article 63 of the Labor Insurance Act: The insured person's spouse, child, parents, grandparents, or dependent grandchildren, brother(s) or sister(s) may also claim for survivor's benefits. In addition, there are more conditions limiting pension payment eligibility. 
Table 2: List of comparison between occupational accident deaths in labor insurance and Labor Standards Act

\begin{tabular}{|c|c|c|}
\hline Terms & Labor Standards Act & Labor Insurance \\
\hline 1. Survivor order & $\begin{array}{l}\text { Same as on the right, but } \\
\text { grandchildren and siblings } \\
\text { are not restricted by their } \\
\text { support. }\end{array}$ & $\begin{array}{l}\text { There are } 1 \text { spouse and children, } 2 \text { parents, } 3 \text { grandparents, } 4 \\
\text { grandchildren supported by them, and } 5 \text { siblings supported by } \\
\text { them. }\end{array}$ \\
\hline $\begin{array}{ll}\text { 2. } & \text { Spouse } \\
& \text { children }\end{array}$ & No limit & $\begin{array}{l}\text { I. The spouse conforms to one of the following } \\
\text { circumstances: } \\
\text { 1. At least } 55 \text { years old and the marriage relationship } \\
\text { has lasted for more than } 1 \text { year. However, this does } \\
\text { not apply to children who are unable to earn a living } \\
\text { or support children in point Il below. } \\
\text { 2. At least } 45 \text { years old, the marriage relationship has } \\
\text { lasted for more than } 1 \text { year, and the monthly work } \\
\text { income does not exceed the first level of the labor } \\
\text { insurance salary scale. } \\
\text { II. Children (adopted children shall have an adoptive } \\
\text { relationship for more than } 6 \text { months) conform to one of } \\
\text { the following circumstances. } \\
\text { 1. Minor. } \\
\text { 2. Inability to earn a living. } \\
\text { 3. Under the age of } 25 \text {, in school, and the monthly work } \\
\text { income does not exceed the first level of the labor } \\
\text { insurance salary scale. }\end{array}$ \\
\hline 3. Parents & No limit & $\begin{array}{l}\text { Parents and grandparents who are at least } 55 \text { years old and } \\
\text { whose monthly work income does not exceed the first level of } \\
\text { the insured salary scale. }\end{array}$ \\
\hline 4. Grandparents & No limit & Same as above \\
\hline 5. Grandchildren & No limit & $\begin{array}{l}\text { 1. Minor. } \\
\text { 2. Inability to earn a living. } \\
\text { 3. Under the age of } 25 \text {, in school, and the monthly work } \\
\text { income does not exceed the first level of the labor } \\
\text { insurance salary scale. }\end{array}$ \\
\hline 6. $\quad$ Siblings & No limit & $\begin{array}{l}\text { 1. Minor. } \\
\text { 2. Inability to earn a living. } \\
\text { 3. At least } 55 \text { years old, and monthly work income does } \\
\text { not exceed the first level of the insured salary scale. }\end{array}$ \\
\hline
\end{tabular}

Data source: Collated as part of this research

The same situation is in the Act for Protecting Workers of Occupational Accidents, which is classified as social insurance payment, but there is no such provision. Imagine a company or employer that normally pays labor insurance and occupational accident insurance premiums. When the worker dies in an unfortunate occupational accident and his/her survivor is claiming the labor insurance benefit, he/she does not meet the requirements and cannot obtain protection quickly, and he/she must seek compensation from the company or employer; you can imagine the state of his/her mind. For companies that obey the law, 100\% of the labor occupational accident insurance premium is paid by the employer, and the labor or the government does not contribute. However, due to the payment conditions of the bureau of Labor Insurance, the payment of insurance premiums cannot be guaranteed, which is good for large enterprises; for small and medium-sized enterprises or even snack bars, in addition to facing compensation from their families in an occupational accident, they also have to deal with labor inspections and various safety improvements, which would be a heavy burden on small and medium-sized enterprises. The purpose of this article is to identify the logical contradictions between the labor insurance, Act for Protecting Worker of Occupational Accidents, the Draft of Labor Occupational Accident Insurance Act, and the Labor Standards Act related to the occupational accident compensation and relief system to establish a reasonable occupational accident compensation system.

This article will discuss using the document analysis method and the case study method. The document analysis method is based on the topic of occupational accidents, through investigation documents and laws and regulations to obtain information, to fully and accurately understand and grasp the current status and laws of "occupational 
accident death payments." The case study method is to investigate and analyze the problems in the current laws and regulations of occupational accidents, to clarify their characteristics and the process of formation, and to investigate and study the existing problems. This research is divided into four sections. In addition to this section, the second section is a document analysis, which analyzes the protection level of the current framework by collecting the current laws and conditions of occupational accidents. The third section is to further analyze the conflicts of laws and regulations through existing problems and related letters of judgment. The final section is the conclusions and recommendations of this article.

\section{il. Literature ReView}

\section{a) Definition of social insurance}

Hsu (2011) expressed that the Bismarck Government in Germany passed the Compulsory Sickness Insurance Act in 1883, compelling employers and employees to jointly pay for participation, creating the first social insurance system and creating the first social insurance system. In addition, Yang (2000) explained that there are several basic principles of social insurance, the most important of which is to assume that social insurance is open and sustainable and that the finances of insurance are sufficient to pay for the benefits. Social insurance has these features: no longer completely indulged in free-market competition, advanced prevention instead of relief after the fact, and we generally call it social insurance; it is currently a major social welfare system project in developed countries.

Labor insurance is the most representative social insurance in various countries, mainly because it covers the vast majority of the working population, and its payment is closely related to the protection of people's right to work. Its reform has become the focus of state governance. Ko (1997) explained that labor insurance, also known as laborer insurance or worker insurance, is a type of social insurance. Taiwan's labor insurance was started from 1950 to April 2020; it has 572.431 insured units, 10,484,046 insured persons, and an average insured salary of NT\$32,5464. Labor insurance can be one of Taiwan's very important social insurance systems. The breadth and depth of its coverage are rare in other social insurances, and it can be the most important pillar of Taiwan's social security system. Labor insurance is established to protect workers. This can be found in Article 1 of the Labor Insurance Act: "This Act is enacted to protect workers' livelihood and promote social security. Matters not provided herein shall be governed by other relevant laws or regulations."

${ }^{4}$ Data is a summary of statistics of the Bureau of Labor Insurance in April 2020.
Furthermore, the High Administrative Court and Administrative Litigation Division of the District Court mentioned in the symposium on September 17, 2018 that the nature of labor insurance is social insurance and is on-the-job insurance for labor. It is not only devoted to protecting labor's life but also has the effect of promoting social safety. For public welfare purposes, it uses the compulsory method and shares risks by the state, the insured units and insured persons to incorporate the working labor into the social insurance system as much as possible so that the worker or his/her beneficiaries can be based on the labor insurance contract when a specific insurance accident occurs and receive a living allowance. Among them, the insured units referred to in the Labor Insurance Act means the units must purchase labor insurance for the insured person; in addition, when the insured units are employers, they shall pay accident insurance premiums (70\%) and occupational accident insurance premiums (full payment) for the insured person based on the insured person's total monthly salary. If the insured units are employers, the status is equivalent to the proposer of the insurance contract (see Article 3 of the Insurance Act). Moreover, since they are instructed by the state to ensure its employed workers to protect their lives, they have insurance interest in the subject matter of the insured, rather than just the actual interest.

\section{b) Identification of international occupational accidents}

Liu and Hsu (2009) expressed that since the twentieth century, advanced industrial countries have gradually developed a set of occupational accident insurance systems, which partially replaced the responsibilities of the government and have also formed the core of occupational accident labor protection systems in various countries. According to the 2004 statistics of "Social Security Programs throughout the World" of the US Social Security Administration, more than 168 countries worldwide have implemented occupational accident insurance systems.

The Occupational Accident Insurance (UnfalIversicherung) is based on Bismarck's social state concept. As early as 1871, when the German Empire was founded, the "Empire Mandatory Liability Act" (Reichhaftpflichtgesetz) was promulgated, certain legal responsibilities shall be given to business owners in specific industries, such as mining, to protect the livelihood of their employed workers in the event of occupational injuries and illnesses. This Act regulates the compulsory law and the employer's responsibilities under private law, the earliest occupational accident protection system. Shieh (2010) indicated that after the Empire Accident Insurance Act (Unfallversicherungsgesetz) was promulgated in 1884, it formally intervened with the power of the state to form the right of employees to claim payment from the state's public law after the accident. 
According to the explanation of Tang (1992), the United Nations International Labor Organization (ILO) has formulated the following: Convention of "Agricultural Workers' Compensation for Accidents," Convention of "Workers' Accident Compensation," Convention of "Workers' Occupational Disease Compensation," Convention of "Compensation of Foreign Workers and Domestic Workers Should Be Treated Equally," Convention of "Occupational Injury Payments," etc. In addition, there are various related proposals, which serve as the basis for each member state to formulate an occupational accident compensation system, urge each member state to formulate it and stipulate occupational accident compensation standards and related matters as norms in labor legislation.

While Huang (2012) expressed that due to labor occupational accident compensation in Europe, it was only based on the Common Law in the past, and the Employer's Liability Act with Faulty adopted the liability without fault to stipulate that employers should be responsible for various obligations of their workers. However, when the worker is injured, it is necessary to prove that the occurrence of the accident was caused by the intention or fault of the employer or his work partner as a compensation element. Otherwise, the employer will not pay compensation. Therefore, various enterprises often dispute compensation for worker occupational accidents due to legal interpretations and adopt a liability without fault system, which stipulates that worker accidents are caused by their duties or accidents caused by the performance of their duties. Regardless of whether there is a fault or not, all employers shall be liable for compensation to solve the problem of compensation for occupational accidents, and then maintain the life safety of workers and the improvement of the labor force.

The International Labor Organization's interpretation of an occupational accident is: "It is based on occupational traumatic injuries or diseases, which can cause the victim to suffer temporary or permanent disability or death, and is not caused by the victim's intentional or gross fault." From this interpretation, it is understood that the criteria for identifying occupational accidents are based on the causal relationship between accidental accidents and the performance of duties. In addition, Lai (2006) defined the labor accidents in Paragraph 1, Article 2 of the Japanese Labor Safety and Health Act as: "Buildings, equipment, raw materials, gases, vapors, dust, etc., or work activities and other businesses related to the worker's employment which can cause injury, illness or death." Meanwhile, Lin and Liu (2010) also showed that occupational accidents, also known as labor accidents, are a type of accidental accidents, and they are accidents caused by workers in a working environment that lacks safety controls or insufficient safety controls.

\section{c) Identification of occupational accidents in Taiwan}

Taiwan's Labor Standards Act and the Act for Protecting Workers of Occupational Accidents do not have defined provisions for "occupational accidents." However, by the latter paragraph of Paragraph 1, Article 1 of the Labor Standards Act, if this Act does not provide for it, the provisions of other laws shall apply. According to the "Occupational Safety and Health Act" (former name: Labor Safety and Health Act, from now on referred to as the Occupational Safety Act), Article 2 of the Occupational Safety Act amended and promulgated in 2013, the term "occupational accidents" referred to in this Act means any diseases, injuries, disabilities, or death of workers caused by buildings, machinery, equipment, raw materials, materials, chemicals, gases, vapors, dust, etc., at the place of duty $^{5}$, or as a result of work activities, or due to other occupational causes ${ }^{6}$. As for the definition of labor, the Labor Standards Act and the Occupational Safety and Health Act are roughly the same, and both refer to those employed to work and receive wages.

Therefore, "occupational accidents" can be regarded as labor accidents caused by occupational reasons such as the employer's provision of workplace safety and sanitation equipment ${ }^{7}$. Occupational accidents, also known as labor accidents, are a type of accidental accident, which refer to accidents that happen to workers in an operating environment that lack safety controls or insufficient safety controls. The criteria for identifying occupational accidents shall meet the following requirements: 1 . "Arising in the course of employment": the accident is the status that occurs in the process of labor performing duties. It is based on the labor contract under the supervision of the business owner. This can be roughly summarized into the following three situations: (1) Work under the control of the employer; (2) Work under the control of the employer but not do the job; 3. Work under the control of the employer but not under the management of the employer (realistic supervision). 2. "Arising out of employment" means that there is a causal relationship between the duty and the accident, and this causal relationship can be divided into the establishment of

\footnotetext{
${ }^{5}$ Place of duty referred to in subparagraph 5 , Article 2, Paragraph 1 , Article 36 and Paragraph 2, Article 37 of the Act includes the following places:1.For the duration of the labor contract, the place where the employer assigns laborers to carry out work services to fulfill the terms of the contract.2.The actual place where self-employed workers engage in work.3.The actual place where other people engaged in work and directed or supervised by the responsible people in workplaces engage in work.

${ }^{6}$ Article 5 of the Enforcement Rules of the Occupational Safety and Health Act, the occupational reasons referred to in Paragraph 5, Article 2 , this Act refers to those who have a considerable causal relationship in all necessary labor activities and their accompanying behaviors derived from work activities.

71989 Tai-Shang-Tzu-No.371 Judgment of Supreme Court.
} 
responsibility and the scope of responsibility, and all the relationships should be identified based on the equivalent causality ${ }^{8}$.

Whether commuting accidents can be regarded as occupational accidents, and the application of the provisions of compensation for occupational accidents, it should be considered whether it is placed under the command and supervision of the employer. It is a car accident or other accidental accident that occurs when a worker must travel through to and from work. It is not a natural hazard caused by occupation or work. It is an illegal infringement by a third party and should not be an occupational accident.

Labor insurance is social insurance, and in principle, commuting accidents are regarded as occupational accidents. However, if the insured has an accident due to traffic violations and other reasons attributable to him/her, labor insurance does not regard it as an occupational accident. Conversely, as far as employers are concerned, the danger of workers traveling to and from the workplace is beyond their control. If commuting accidents are regarded as occupational accidents under the Labor Standards Act, as long as the accident occurs on the way to and from the workplace, regardless of whether the worker is accountable or not, it is all due to reasons for the worker. The basic law's compensation for occupational accidents adopts no-fault liability, and employers shall bear the responsibility for compensation for occupational accidents, which seems unfair to employers.

Cheng (2009) stated that although the protection of labor rights is the legislative purpose of the Labor Standards Act, the promotion of economic development is also one of the legislative purposes. Regarding commuting accidents as occupational accidents under the Labor Standards Act, there is still room for discussion whether it will unreasonably aggravate employers' responsibilities, affect their competitiveness, and hinder economic development.

\section{d) Taiwan labor insurance and occupational accident death compensation}

Huang (2012) explained that employment accident insurance is the most commonly implemented labor welfare measure in the social insurance system. The occupational accident compensation system is a typical system that transitions from labor law to social law. The early occupational accident compensation was based on employer liability, supplemented by insurance liability. There was even a tendency to break away from the employer's liability and become purely social liability insurance. Taiwan's current occupational accident compensation system includes, in addition to labor insurance and the Act for Protecting Worker of

\footnotetext{
${ }^{8} 2007$ Lao-Shang-I-Tzu-No.32 Civil Judgment ofTaiwan High Court.
}

Occupational Accidents that came into effect in 2002, and the Draft of Labor Occupational Accident Insurance Act currently sent to the Executive Yuan.

The regulation in Paragraph 1, Article 63 of Labor Insurance Act: "In the event of the death of an insured person during the effective period of the insurance, the person who pays for the funeral could claim for the funeral grant. Furthermore, the insured person's spouse, child, parents, grandparents, or dependent grandchildren, brother(s) or sister(s) may also claim for survivor's benefits." 9 If the insured person has insurance seniority before the amendment of the provisions of this Act in 2008 came into effect, his/her survivors may not only claim annuity payments by the preceding paragraph but also choose to apply for a lump sum survivor allowance. The restrictions in the preceding paragraph shall not be changed after verification and payment by the insurer. The funeral grant is paid to the insured person in a five-month lump sum based on the average monthly insured salary. ${ }^{10}$ If you choose to apply for the lump-sum survivor's allowance, the insured's average monthly insured salary will be paid for 40 months. Those who apply for survivor's annuity ${ }^{11}$ : according to the total insurance years of the insured, it is calculated as $1.55 \%$ of the average monthly insurance salary for each full coverage year.

The regulation in Paragraph 1, Article 64 of Labor Insurance Act specifies that survivors who meet the requirements of Paragraph 2, Article 63 of the same

\footnotetext{
${ }^{9}$ The regulation in Paragraph 2, Article 63 of Labor Insurance Act: The conditions for spouses and children to claim survivors' pension benefits are: (I) The children meet one of the following circumstances: (1) Minor. (2) Inability to earn a living. (3) Under 25 years old, in school, monthly work income does not exceed the Level 1 of the insured salary scale. (II) The spouse meets one of the following circumstances: (1) Over 55 years of age, and the marriage relationship has lasted for more than one year. (2) Be at least 45 years old and have a marriage relationship for more than one year, and the monthly work income does not exceed the Level 1 of the insured salary scale. (3) Inability to earn a living. (4) Support the children mentioned in (I) above." (III) In addition, the conditions for parents and grandparents to apply for survivors' pension benefits are: "Those who are at least 55 years old and whose monthly work income does not exceed the Level 1 of the insured salary scale." (IV) The conditions for grandchildren to apply for survivors' pension benefits are same children. (V) Brothers and sisters meet one of the following conditions (1) Minor. (2) Inability to earn a living. (3) "Those who are at least 55 years old and whose monthly work income does not exceed the Level 1 of the insured salary scale."

10 Subparagraph 2, Paragraph 3, Article 19 of Labor Insurance Act: funeral grant and survivor allowance are calculated based on the average actual monthly insured salary of the insured person in the first six months from the month in which the insurance accident occurred.

${ }^{11}$ Subparagraph 1, Paragraph 3, Article 19 of Labor Insurance Act: It is calculated by averaging the highest sixty monthly insurance salary during the period of joining insurance coverage; for those who join the insurance for less than five years, it would be calculated using the average monthly insurance salary for the actual insurance period.
} 
Act may apply for the survivor's pension benefit and a lump sum payment of ten months of occupational accident death compensation based on the average monthly insured salary of the insured. However, if the survivor does not meet the conditions for claiming the survivor's pension or survivor's allowance, or if there is no survivor, he/she will receive a ten-month funeral grant based on his/her average monthly insured salary. This is stipulated in Subparagraph 1, Article 63-2 of the Labor Insurance Act ${ }^{12}$.

Paragraph 1, Article 65 of the Act stipulates that "survivors' pension benefits and survivors' allowance shall be payable to the entitled survivors(s) according to the order prescribed below: 1. spouse, son and daughter; 2. father and mother; 3. grandfather and grandmother; 4. grandson and granddaughter; 5. brother(s) and sister(s)." Among them, grandchildren or brother(s) and sister(s) need to be supported by them before they can apply for the survivor's pension ${ }^{13,14}$. Paragraph 2 of the same Act stipulates: "Survivors listed on the rear order as stipulated in the previous paragraph are not entitled to apply for survivor's pension benefits or survivor's allowance if survivors listed on the front still exist." For the payment of the survivor's pension, there is another provision to stop the payment ${ }^{15}$. In addition, the survivors of the first order have unknown whereabouts or are abroad. Submit a waiver petition. If the claim is not filed within one year after meeting the requirements, the survivors in the second order may apply for the survivor's pension. Based on the principle of non-repetitive payment of social insurance, when the beneficiary meets the conditions for claiming a disability pension, old-age pension, or survivor's pension, it is necessary to choose one to claim disability, old-age payment, or survivor's allowance ${ }^{16,17}$.

\footnotetext{
12 Administrative Appeal Decision Lao-Su-Tzu-No.0990003494 Council of Labor Affairs, Executive Yuan.

${ }^{13}$ The regulation in Paragraph 1, Article 1117 of Civil Code: "Persons entitled to maintenance shall be limited to those who cannot support the living and are unable to earn a living."

${ }^{14}$ To further explain the "scope of the inability to earn a living," the predecessor of the Ministry of Labor, the Council of Labor Affairs, Executive Yuan, issued an explanation in the letter of Labor InsuranceII-Tzu-Decree No. 0970140586.

${ }^{15}$ Article 63-4 of Labor Insurance Act: Survivors pension payments shall be suspended if the survivors have one of the following conditions during the receiving period: 1. Spouse: (1) Re-married; (2) is less than 55 years of age and the children he/she supports are not qualified for the application conditions stipulated in the second subparagraph of the second paragraph of Article 63; (3) doesn't conform to the claiming criteria stipulated in the first subparagraph of the second paragraph of Article 63. 2.Children, parents, grandparents, grandchildren, brothers, and sisters who don't conform to the claiming criteria in second to the fifth subparagraph of the second paragraph of article 63.3.Should there is any condition as described in the third and fourth subparagraph of the third paragraph of Article 54-2.

${ }^{16}$ The regulation in Paragraph 3, Article 65 of Labor Insurance Act: "Should the survivors listed in first-order are all disqualified for the survivors pension payments or having one of the following conditions
}

\section{ili. Case Study}

\section{a) Offset of labor occupational accident death compensation}

\section{i. Offset of labor insurance}

The occupational accident compensation items and standards in the Labor Insurance Act are stipulated in Article 59 of the same Act, among which Paragraph 1 of the Act states: When an occupational accident causes death, disability, injury or illness to a worker, the employer shall compensate according to the following provisions. However, for the same accident, according to the labor insurance regulations or other laws and regulations, if the employer has paid the compensation, the employer may offset it; and the occupational accident insurance premium is borne by the employer in full, so the insurance payments can fully offset the compensation fees for occupational accidents stipulated by the Labor Insurance Act. ${ }^{18}$ And to avoid the employer's double burden, the proviso stipulates that following the Labor Insurance Act or other laws and regulations, the employer may offset the compensation for expenses paid by the employer. ${ }^{19}$ The employer's liability for compensation under Article 59 of the Labor Insurance Act is a statutory compensation liability, which is different from the liability of compensation for torts under the Civil Code. Article 60 of the Labor Insurance Act stipulates that the amount of compensation paid by an employer by Article 59 of the same Act may offset the amount of compensation for damage caused by the same accident.

Moreover, the labor occupational accident insurance is the Bureau of Labor Insurance established by the central competent authority as the insurer, and the employer is responsible for the insurance premium. When the worker experiences an occupational accident, the worker receives insurance payments. This is in line

when there is no survivor qualified in the same order, the survivors in the second-order could claim for survivors pension benefit: 1. die while claiming the survivor pension benefit; 2 . nowhere to be found or are in overseas; 3. submit a claiming waiver; 4 . don't apply within one year when qualified for claiming benefits." The regulation in Paragraph 4, Article 65 of Labor Insurance Act: "When the survivor in the first-order of the previous paragraph claim the benefits or re-confirm to the claiming criteria, the benefit would not be granted to other survivors, and the survivors in the first-order could claim the benefits; however, if the benefits are already granted to the survivors in the second-order, the benefits would not be reissued to the survivors in the first-order."

${ }^{17}$ Article 65-3 of Labor Insurance Act: The insured person or his/her beneficiary is entitled to apply for only one kind of benefit if he or she is qualified for disability pension, old-age pension payments, or survivors pension benefit at the same time.

18 Please refer to (1986) Tai-Nei-Lao-Tzu-Letter No.374797 of the Ministry of the Interior.

19 Please refer to Tai-(1995) Labor-III- Tzu-Letter No.11182 of the Council of Labor Affairs, Executive Yuan. 
with the labor occupational accident insurance of the Labor Insurance Act. The purpose of the compensation is similar, and it is a system that guarantees the compensation for workers' occupational accidents and reduces the employer's financial burden. ${ }^{20}$ It can also avoid the damages caused by workers or other claimants in the same occupational accident. For the employer, it is a repeated request, and there is the principle of offsetting gains and losses ${ }^{21}$. The legislative spirit of the offset provisions aims to avoid the double benefit to workers and to protect the employer's payment of insurance premiums to protect the workers' payments. ${ }^{22}$

ii. Compensation for occupational accidents in the Labor Insurance Act adopts a no-fault offset application

The compensation provisions in Article 59 of the Labor Insurance Act are special provisions for protecting labor, strengthening labor-employment relations, and promoting social and economic development, and are not compensation for damages. Article 61 of the same Act also stipulates that the right to receive compensation shall not be offset, and Article 217 of the Civil Code shall not be applicable for fault. ${ }^{23}$

Also, according to occupational accident compensation, it is a system that provides timely and effective salary payments, medical care, and labor reconstruction measures to employees who have suffered "work-related injuries." This ensures that employees and their dependent family members will not fall into poverty, thus causing social problems. Its purpose is not to impose sanctions or impose responsibilities on employers who violate their obligations or have a deliberate fault, but to protect the right to survival of workers and their families and to preserve or rebuild the labor force of individuals and society. The characteristic of the accident compensation system is to adopt the principle of no-fault liability. All employers shall be liable for compensation for the occurrence of occupational accidents, regardless of whether they have an intentional fault or not. Even if the employees are at fault, they shall not be derogated from due rights. ${ }^{24}$

Therefore, Article 59 of the Labor Insurance Act stipulates that employers adopt the principle of no-fault

\footnotetext{
20 Please refer to 2016 Tai-Shang-Tzu-Civil Judgment No.44 of Supreme Court.

${ }^{21}$ Please refer to 2015 Chung-Lao-Shang-Tzu-Judgment No.53 of Taiwan High Court.

${ }^{22}$ Please refer to 2004 Su-Tzu-Civil Judgment No.113 of the Taiwan Keelung District Court.

${ }^{23}$ Please refer to the $4^{\text {th }}$ Civil Court Meeting of the Supreme Court in 2000.

${ }^{24}$ Please refer to 2015 Lao-Shang-I-Tzu-Civil Judgment No. 86 of Taiwan High Court.
}

liability; that is, employers shall not refuse to pay compensation because they think they are not at fault. ${ }^{25}$

\section{iii. The problem of offsetting occupational accidents}

By Article 59 of the Labor Insurance Act, An employer can only pay compensation following the provisions of the Labor Insurance Act or other applicable statutes and administrative regulations. The employer may deduct any compensation already paid. Therefore, it is common for employers not to insure the workers under the company, and the workers themselves join the insurance under the occupational union. The employer has not provided insurance for the labor declaration, but the occupational union has joined the insurance. In the event of an occupational accident, the employers are not allowed to offset the occupation accident payments of labor insurance received ${ }^{26}$. In addition, when a worker dies due to an occupational accident, the employer shall pay the insurance premium for the insurance claim paid by commercial insurance for the injured worker due to the same accident. The beneficiary shall be as stipulated in Subparagraph 4, Paragraph 1, Article 59 of the Labor Standards Act. In the case of different or non-ranked persons, the employer can still offset the compensation for occupational accidents by the provisions of the Labor Standards Act. If there are still shortcomings, the employer should make up for it by the compensation order stipulated in the Act. ${ }^{27}$ In addition, the spouse, children, and parents of workers who died due to occupational accidents have their independent right to claim damages against their employers. Article 59 of the Labor Standards Act also stipulates that the survivors of workers have special provisions on the order of death compensation. The survivors inherit and jointly receive the compensation, so the employer cannot claim the compensation amount received by others to offset the damage compensation amount of the person who has not received the compensation. ${ }^{28}$

By the provisions of Article 59 of the Labor Standards Act, the employer may offset the compensation between labor insurance and occupational accident insurance payments and the compensation obligations of the Labor Standards Act. Among them, Article 34-1 of the Enforcement Rules of the Labor Standards Act, in the case where a worker encounters the event of death or disability due to an occupational accident, if the employer has insured

\footnotetext{
25 Please refer to 1998 Tai-Shang-Tzu-Verdict No.1629, 1998 TaiShang-Tzu-Verdict No.233 of Supreme Court.

26 Please refer to (1989) Tai-Labor-III- Tzu-Letter No.23866 of the Council of Labor Affairs, Executive Yuan.

${ }^{27}$ Please refer to Fu-Lao-An-Tzu-Letter No.0960103792 of the Tainan County Government.

${ }^{28}$ Please refer to the Forum on Civil Code Issues of Taiwan High Court and Subordinate Court in December 1999.
} 
him/her by the Labor Insurance Act and the accident has been approved by the insurer as an occupational insurance accident, the employer shall provide compensation by Article 59 of this Act based on the average wage of the worker and the difference in average insured salary shall be calculated by the standards specified in the third and fourth subparagraphs of Article 59 of this Act. The system is updated, and in response to the application of labor insurance pension, the disability benefit of labor insurance offsets the Labor Standards Act occupational accident and disability compensation method and technically avoids the difficulty of calculating the total pension benefit (Hsu, 2017). Therefore, if the employer has already paid labor insurance for the worker, on the one hand, the worker can request disability payments from the insurer based on his/her average insured salary. On the other hand, he/she can follow Article 34-1 of the Enforcement Rules of the Labor Standards Act and Subparagraph 3, Article 59 of the Labor Standards Act. According to the provisions, the employer is requested to pay compensation for the disability from an occupational accident based on the difference between the average salary and the average insured salary. There is no problem that the overlapping part should be offset. $^{29}$

Table 3: Death compensation for the occupational accident of the insured persons of labor insurance

\begin{tabular}{|c|c|c|}
\hline Term & The Labor Standards Act & The Labor Insurance Act \\
\hline $\begin{array}{l}\text { Occupational } \\
\text { Accident }\end{array}$ & $\begin{array}{l}\text { Follow Article } 2 \text { of the Occupational Safety and } \\
\text { Health Act }\end{array}$ & $\begin{array}{l}\text { Article } 34 \text { of the Labor Insurance Act and the } \\
\text { Regulations of the Examination of Injuries and } \\
\text { Diseases Resulting from the Performance of Duties } \\
\text { by the Insured Persons of the Labor Insurance } \\
\text { Program }\end{array}$ \\
\hline Commuting Accident & $\begin{array}{l}\text { If it does not violate Article } 18 \text { of the Regulations of } \\
\text { the Examination of Injuries and Diseases Resulting } \\
\text { from the Performance of Duties by the Insured } \\
\text { Persons of the Labor Insurance Program, it shall be } \\
\text { considered as occupational accidents. }\end{array}$ & Same as on the left \\
\hline Beneficiary Order & $\begin{array}{l}\text { Subparagraph 4, Paragraph 1, Article } 59 \text { of the } \\
\text { Labor Standards Act }\end{array}$ & Paragraph 1, Article 63 of the Labor Insurance Act \\
\hline Funeral Grant & Funeral expenses for five months' average salary & $\begin{array}{l}\text { Subparagraph 1, Paragraph 1, Article } 63-2 \text { of the } \\
\text { Labor Insurance Act }\end{array}$ \\
\hline $\begin{array}{l}\text { Death } \\
\text { Compensation } \\
\text { (Survivors' } \\
\text { Allowance) }\end{array}$ & $\begin{array}{l}\text { Death compensation for forty months' average } \\
\text { wages should be given to the survivors in one lump } \\
\text { sum }\end{array}$ & Paragraph 2, Article 64 of the Labor Insurance Act \\
\hline Survivors' Pension & None & $\begin{array}{l}\text { 1. Subparagraph 2, Paragraph 1, Article 63-2 of } \\
\text { the Labor Insurance Act } \\
\text { 2. Paragraph 1, Article } 64 \text { of the Labor Insurance } \\
\text { Act } \\
\text { 3. For those with insurance seniority before the } \\
\text { implementation of the revised provisions on } \\
\text { July 17, 2008, the survivors' allowance and } \\
\text { survivors' pension can be applied for either. }\end{array}$ \\
\hline
\end{tabular}

Data source: Collated as part of this research

\footnotetext{
${ }^{29}$ Please refer to 2015 Chung-Lao-Shang-Tzu-Judgment No.53 of Taiwan High Court.

30 The Ministry of Internal Affairs, the former central labor administrative authority, also made the same explanation in (1986) Tai-Nei-Lao-No. 374797.
} 
b) Labor Insurance Survivors' Pension Restrictions and Employers' Risk Liabilities

This research will illustrate the restrictions of receiving labor insurance survivors pension and the employer's risk liabilities through the following eight questions and related administrative interpretations and judgments.

Question 1: Among the order of receiving survivor's pension and survivor's allowance, the rank fourth grandchildren and the rank fifth brother(s) and sister(s) are all subject to their support restrictions. The order of compensation for occupational accidents in the Labor Standards Act is the same, but there is no restriction on their support qualifications in the Labor Standards Act. As a result, the rank fourth grandchildren and the rank fifth brother(s) and sister(s) cannot apply for labor insurance payments if they do not meet the eligibility requirements. Although the employer pays $100 \%$ of the occupational accident insurance premiums for labor insurance, the survivors of occupational accident workers cannot apply for labor insurance payments; in addition, the employer is also responsible for the compensation liability in the Labor Standards Act.

Related administrative interpretations and judgments:

The survivors' allowances in Article 63 and Article 64 of the Labor Insurance Act are based on ethical relationships between spouses, children, parents, and grandparents. They shall all be received by Article 65 of the same Act. The rest of the grandchildren and brothers and sisters shall have the fact that they are exclusively supported by the insured before receiving the payments, which is based on the principle that the survivors should be taken care of it. However, given the survivors' allowance, as stipulated in the above regulations, the survivors' allowance was originally set up to subsidize the living expenses of the survivor that the insured had supported before his/her death to avoid displacement and life in desperation. Therefore, the survivors' allowance should also be insured. The fact of support and inability to earn a living is the essential requirement, and it is by the preceding constitutional decree. ${ }^{31}$

Question 2: Labor insurance survivors receive survivors pension benefits and survivors' allowances. In addition to the order of the survivors, there are also restrictions on the survivors' conditions. As long as the survivors do not meet the requirements, they cannot apply for labor insurance survivors' pension and survivors' allowances. However, the employer is still responsible for compensation in the Labor Standards Act.

Related administrative interpretations and judgments:

By Subparagraph 3, Paragraph 2 and 3, Article 63 of the Labor Insurance Act, parents under the age of

\footnotetext{
${ }^{31}$ Please refer to J. Y Interpretation No.549
}

55 are not eligible for claiming survivors' pension payments or the survivors' allowance conditions. Still, under the provisions of Subparagraph 1, Paragraph 1, Article 63-2 of the same Act, the survivor can still request a ten-month funeral grant based on the average monthly insured salary. ${ }^{32}$

Question 3: When the survivor is eligible to receive two or more survivors' pension benefits, they should choose one to apply. The survivors' pension application that caused the survivor's abandonment of employment shall be changed to the employer.

\section{Related administrative interpretations and judgments:}

Under Paragraph 3, Article 63-3 of the Labor Insurance Act, if there are more than two survivors in the same order, and one of them applies for the survivor's pension, the payment shall be issued to the survivor's pension payment. Those who apply for the survivor's pension shall meet the requirements for the survivor's pension benefits. Therefore, the spouse currently does not meet the requirements for the survivor's pension benefits and can only apply for the survivor's allowance. $^{33}$

Question 4: The insured has died due to an occupational accident, and the survivors do not meet the requirements for claiming survivors' pension benefits. It is also not possible to claim the lump sum of ten-month occupational accident death compensation. As long as the survivor does not meet the requirements for claiming the survivor's pension benefits, even the ten-month occupational accident death compensation cannot be received.

Related administrative interpretations and judgments:

According to Article 64 of the Labor Insurance $\mathrm{Act}^{34}$, has specified that if the insured person died due to occupational accidents, the beneficiary could claim the survivor's pension benefits and occupational accident death compensation lump-sum payment if the beneficiary meets the conditions for payment of the survivor's pension. The survivor's pension payment and occupational accident death compensation lump-sum payment cannot be claimed separately. According to this, if the survivor does not meet the survivor's pension application requirements, he/she cannot apply for the death compensation lump-sum payment for the occupational accident. If the survivor meets the survivor's pension application requirements, the Bureau will issue the survivor's pension and occupational accident death compensation lump-sum payment. In the future, the survivors will meet the requirements for

\footnotetext{
32 Please refer to2015 Lao-Shang-I-Tzu-Civil Judgment No.108 of Taiwan High Court.

${ }^{33}$ Please refer to the Labor Insurance-II-Tzu-Letter No. 0990082761 of the Council of Labor Affairs, Executive Yuan.

${ }^{34}$ Please refer to the Labor Insurance-III-Tzu-Letter No.1050140304 dated June 2, 2016, of the Ministry of Labor.
} 
survivor's pension payment in Paragraph 2, Article 63 of the same Act, and the survivors may apply for survivor's pension payment and death compensation lump-sum payment for the occupational accident. In addition, the original 10-month funeral grant does not need to be returned, and it will be explained.

Question 5: Should the survivors listed in first-order are all disqualified for the survivor's pension payments or having one of the following conditions: nowhere to be found or are overseas, submit a claiming waiver, don't apply within one year when qualified for claiming benefits; and when there is no survivor qualified in the same order, the survivors in the second-order could claim for survivor's pension benefit.

However, the employer is still responsible for the compensation liability in the Labor Standards Act for the survivors listed in the first order. This may cause the survivors of the first order to abandon the claim and the second-order to claim, but the employer still has to pay the first order survivors. The employer is responsible for compensation under the Labor Standards Act.

Related administrative interpretations and judgments:

Paragraph 3, Article 65 of the Labor Insurance Act: If the insured person has a first-order survivor (i.e., spouse or children), the rear order survivor (parents) cannot apply. However, if the parents of the insured person are in the same circumstances as stipulated in Paragraph 3, Article 65 of the Act, they may apply to the Bureau for survivors' pension benefits. If the spouse and children of the first order do not file a claim within one year of meeting the requirements, the parents of the second-order can also apply for the survivors' pension benefits one year after the death of the insured person. Still, this rule only applies to the second-order (parents) and shall not extend to the survivors below the third order. In addition, if the insured person has insurance coverage seniority before January 1, 2009, the beneficiary in the current order cannot claim the survivor's allowance. The beneficiary shall issue a claim waiver (but if the beneficiary is a minor, he/she shall not waive the claim). The claimed waiver shall be stamped with a seal certificate, and the seal certificate shall be attached or certified by the court or a private notary public. The subsequent beneficiary may apply for the survivor's allowance within the 5-year claim time limit and explain.

Question 6: When the insured person, or his/her beneficiaries meet the conditions for claiming disability pension, old-age pension, or survivor's pension, they should choose one of them to claim disability, old-age benefits or survivor's allowance. If the survivors renew their disability pension or old-age pension and waive application for the survivor's pension and turn to the employer to seek compensation, the employer still has to bear the compensation liability under the Labor Standards Act.
Related administrative interpretations and judgments:

Article 64 of the Labor Insurance Act $^{35}$ has specified clearly that if the insured person died due to an occupational accident, the beneficiary could only apply for the survivor's pension benefit and occupational accident death compensation when the beneficiary meets the conditions for the survivor's pension benefit and death compensation lump-sum payment for the occupational accident, and the two cannot be claimed separately. By Article 65-3 of the same Act, if the beneficiary has chosen to receive his/her old-age pension benefit but does not choose to receive the survivor's pension benefit, he/she shall not be allowed to separately claim a death compensation lump-sum payment for the occupational accident.

A worker who died of an occupational accident was insured by the employer by the Labor Insurance Act. ${ }^{36}$ The insurer has approved occupational accident insurance, and the survivors of the worker have received labor insurance payments due to "the same accident" or when the employer pays the insurance payments according to other laws and ordinances, the employer can only offset its death compensation according to the Labor Standards Act. If the worker dies in an occupational accident, his/her survivor is eligible to claim the survivor's pension and renew his/her old-age pension by Article 65-3 of the Labor Insurance Act. As a result, he has not received the survivor's pension payment, which is not consistent with the same accident. If the employer has paid compensation for expenses, the employer shall still pay the survivors 40 months of average wages for death compensation and five months of average wages for funeral expenses under the Labor Standards Act. However, if the survivor receives the funeral grant of the 10-month average monthly insured salary under the provision of Paragraph 1. Article 63-2 of the Labor Insurance Act, the employer may claim this part to offset the funeral expenses and death compensation of the Labor Standards Act, and the shortfall shall still be made up by the employer.

Question 7: Commuting Accidents, the injuries suffered by workers in traffic accidents while commuting are not caused by equipment or operating activities in the workplace, and occupational reasons, which are not within the course of employment, and workers on the way to and from the workplace are also not within the scope of the command and supervision of the employer. The hazard occurs due to factors beyond the employer's control. However, as long as the worker does not violate the provisions of the Regulations of the Examination of Injuries and Diseases Resulting from the Performance of Duties by the Insured Persons of the

\footnotetext{
${ }^{35}$ Please refer to the Labor Insurance-III-Tzu-Letter No.1050140304 dated June 2, 2016, of the Ministry of Labor.

36 Please refer to Labor Act-II-Tzu- Letter No. 1050130149 of the Ministry of Labor.
} 
Labor Insurance Program, the commuting accident is an occupational accident.

Related administrative interpretations and judgments:

Article 4 of the Regulations of the Examination of Injuries and Diseases Resulting from the Performance of Duties by the Insured Persons of the Labor Insurance Program established by the former Council of Labor Affairs, Executive Yuan according to Paragraph 2, Article 34 of the Labor Insurance Act stipulates that the insured person shall commute to and from the workplace at appropriate times and by appropriate means of transportation to and from the place of employment. Injuries caused by accidents during the commute are regarded as occupational injuries. The occupational accidents in Article 59 of the Labor Standards Act shall also are interpreted in the same way. ${ }^{37}$

Paragraph 1, Article 4 of the Regulations of the Examination of Injuries and Diseases Resulting from the Performance of Duties by the Insured Persons of the Labor Insurance Program: "Insured persons incur injuries resulting from accidents occurred while they are on and off duty, at the proper time, on the way of round trips from daily residences to employment places, or for another duty between employment places, injuries are considered as occupational injuries." Article 18 stipulates: "In case insured persons under the stipulation of Article 4, 9, 10, 16 and 17 incur injuries from conditions as follows, injuries shall not be considered as occupational injuries: (1) Personal activities are not necessary for daily life. (2) Drivers have no drivers' license of types of cars for driving. (3) Drivers are under the period of invalidation or taking disciplinary action against the invalidation of their drivers' license. (4) Persons drive against traffic regulations and barge into the red light while they pass through intersections with restraints of light marks. (5) Persons barge into the crossover of railways. (6) Persons drive their cars while their alcohol concentrations are over the stipulation standard; they take drugs, psychedelic or controlled drugs. (7) Persons drive against traffic regulations on the shoulders of highways. (8) Drivers drive their cars without following the direction that they should obey, or competing to drive, contesting, crawling or driving in other dangerous ways. (9) Drivers drive their cars into the carriageway for coming without depending on stipulations." Therefore, as long as the worker does not violate the Regulations of the Examination of Injuries and Diseases Resulting from the Performance of Duties by the Insured Persons of the Labor Insurance Program, the commuting accident is an occupational accident and the employer shall bear the relevant responsibilities.

\footnotetext{
372018 Tai-Shang-Tzu-No.958 Judgment, 2003 Tai-Shang-Tzu-No. 1960 Civil Judgment, and 2012 Tai-Shang-Tzu-No.544 Civil Judgment of Supreme Court and the results of the 2011 Legal Symposium of the Taiwan High Court and its affiliated courts are available for reference.
}

Question 8: Workers employed by two companies are insured at the same time. If the worker died in an occupational accident in Company A, the survivor can choose one of the companies to receive the labor insurance death benefit. The survivor will likely choose to submit the application to Company B for general death benefits of labor insurance. When requesting compensation for occupational accidents from Company $\mathrm{A}$, even though Company $\mathrm{A}$ has added labor insurance for the worker and paid the insurance premiums in full, it could not cover Company A's liability.

Related administrative interpretations and judgments:

The Council of Labor Affairs (the predecessor of the Ministry of Labor) ${ }^{38}$ explains that employers responsible for compensation under Article 59 of the Labor Standards Act for employees who were engaged in more than two jobs and encountered occupational accidents shall be subject to the same provisions. The amount of the labor insurance benefit offset by the income is based on the compensation for the expenses paid; that is, the employer can only calculate the offset based on the average monthly insured salary declared for the labor insurance participation of the worker. As for the worker's participation in the labor insurance due to other jobs, the payment is higher than the previous amount. As it is not caused by the employer's payment of compensation, there is no valid claim for offset, and it will take effect on the same day.

\section{Conclusion}

To take care of the employees and their dependents, social insurance prevents them from falling into poverty and social problems, but it increases the employer's responsibility. As long as the survivors have experienced one of the factors from Question 1 to Question 8, and the survivors' pension or survivors' allowance of labor insurance cannot be claimed, or they do not meet the requirements due to other factors, the employer still has to bear the responsibility for occupational accident compensation by the Labor Standards Act.

Labor insurance is compulsory insurance with a social welfare nature, which is different from general insurance. Its purpose is to maintain the stability of the basic economic life of workers and their families and prevent the lives of workers and their families from getting into trouble due to the occurrence of individual insurance accidents. To implement the social policy to protect workers, the system design adopts the benefits treatment for workers $^{39}$. Furthermore, the labor occupational accident insurance system makes employers pay insurance premiums, and the state will provide occupational accident compensation on behalf

\footnotetext{
38 Please refer to the Labor-III-Tzu-Interpretation No.0990130102.

${ }^{39}$ Please refer to 2019 Lao-Shang-Tzu-Civil Judgment No.4 of Taiwan High Court.
} 
of employers to ensure the fair and rapid compensation of labor occupational accidents. The payment made by the state under the Labor Occupational Accident Insurance Act is only to reduce the economic burden of the employer, and in essence, is still the labor occupational accident compensation under the Labor Standards Act. ${ }^{40}$ However, for employers, the current occupational accident insurance for workers is paid by the employer in full, but its payment conditions are stricter than commercial insurance. In addition to the disadvantages for the employers, it is also not conducive to the development of the enterprise.

Therefore, the future legislation of the Labor Occupational Accident Insurance Act should not just copy the occupational accident part of the labor insurance and the Act for Protecting Worker of Occupational Accidents. The compensation for occupational accident deaths in Taiwan's current Labor Standards Act is very different from the compensation for occupational accident deaths in labor insurance, which in turn causes losses to enterprises and damage to the labor force. Take Japan as an example, although the Labor Standards Act is still the basic law of compensation for industrial accident insurance, the content and amount of compensation are completely the same. Therefore, it is hoped that the future legislation of the Labor Occupational Accident Insurance Act can solve the current problems or integrate the current labor law on occupational accident compensation. We organize the conclusions as follows:

1. The definition of occupational accidents and the compensation responsibilities for commuting accidents in the labor law shall be unified and consistent to avoid confusion.

2. The beneficiary orders of occupational accident compensation in the Labor Standards Act and the conditions for receiving compensation shall be consistent with the restrictions on beneficiaries and the conditions for receiving survivors' pension or survivors' allowance in the labor insurance or Labor Occupational Accident Insurance Act.

3. The survivors of the Labor Occupational Accident Insurance Act will receive various insurance payments under the Labor Standards Act.

4. Regardless of whether it is the insured person, beneficiaries or survivors under the Labor Occupational Accident Insurance Act, regardless of the name or amount on any insurance payments under the Act, the employer's occupational accident compensation liability can be offset, and any shortfall will be made up by the employer.

5. Regardless of where the two companies apply for labor insurance death payments, the calculation should be based on the average insured salary. If the occupational accident is verified by the Bureau of Labor Insurance, it should be claimed as an occupational accident insurance payment for survivors. The survivors' insurance payment amount can be used to offset the company's occupational accident compensation liability.

\section{References Références Referencias}

1. Chen, Y.-L. (2008), On Occupational Accident Compensation System, Master's thesis of Department and Institute of Financial and Economic Law, National Dong Hwa.

2. Cheng, C.-C. (2009), Commuting Accidents, Taiwan Jurist, 80, pp.25.

3. Hsu, K.-C. (2011), On the Age for Labor Insurance within Social Insurance, Social Fairness and Justice, Angle Publishing.

4. Hsu, W.-N. (2017), The Trend and Suggestions for Taiwan's Draft of the Occupational Injury Insurance Act: A Reference to Japan's Occupational Injuries Act, Cross-Strait Law Review, No. 56, pp. 25.

5. Huang, Y.-C. (2012), New Perspectives on Labor Law (4 ${ }^{\text {th }}$ ed.), Hanlu Book Publishing Ltd.

6. Ko, M.-S. (1997), A Study on the Meanings and Terms of Labor Insurance and Social Insurance, Social Insurance, China Social Insurance Association, pp.36.

7. Lai, C.-P. (2006), Research for the related employers' criminal responsibilities which regarding to the major accidents in Taiwan, Master's thesis of Department and Graduate Institute of Labor Relations, National Chung Cheng University.

8. Lin, F.-P. and P.-T. Liu (2010), The Interpretation of the Labor Standards Act, San Min Book.

9. Liu, L.-W., C.-F. Hsu (2009), A Comparative Study on Measures of Occupational Accidents Prevention and Rehabilitation in Occupational Accidents Insurance Programs, Institute of Labor, Occupational Safety and Health, March, pp.2.

10. Shieh, J.-T. (2010), The Right of Existence with Social Insurance System and the Reform, The Military Law Journal, 56(5), pp.75.

11. Tang, L-R (1992), A Study on Occupational Accident Compensation System in Taiwan, Industrial Safety and Health Monthly, September, pp.7-18.

12. Wang, C. C., Y.-W. Cheng, J.-D. Wang, Y.-L. Guo (2009), Development of Workers' Compensation and the Current System in Taiwan, Taiwan Journal of Public Health, 28, pp.1-10.

13. Yang, C.-L. (2000), Meaning of Social Insurance and Social Welfare System, Taiwan Journal of Social Welfare, 1, pp.160.

\footnotetext{
${ }^{40}$ Please refer to Tai-Shang-Tzu-Civil Judgment No.617 of Supreme Court.
} 